\title{
An Assessment Study on the ''Factors Influencing the Individual Investor Decision Making Behavior"
}

\author{
Dr. Taqadus Bashir(Assistant Pro. at University of Gujrat),Ms. Scholar \\ AaqibaJaved,Ms. Scholar Arslan Ali ButtMs. Scholar NazishAzam,Ms. Scholar \\ Ayesha Tanveer,Ms. Scholar IrtazaAnsar \\ Faculty of Management and Administration Sciences (FMAS) University of Gujrat, Pakistan
}

\begin{abstract}
Behavioral finance assumes that characteristics of market participants and information structure systematically have an influence on individuals' investment decisions. This research paper aims at identifying the factors that influences the Pakistan's individual investor behavior. Thirty four items under the five categories of variables were taken as independent that influences the individual investment decision making behavior that belongs to self-imagelfirm image, neutral information, accounting information, personal financial needs and advocate recommendations. Data collection is made with the help of structured questionnaires. Sample size of 125 was considered for the study out of which 40were finance students of University of Gujrat, 30 were finance teachers from different colleges and 55were bank employees of Sialkot, Gujranwala, Lahore and Gujrat. The statistical tools that were used for data analysis were mean, standard deviation, frequency distribution table of variables that have significant influence on decision making and frequency distribution table of variables that have least influence on decision making. Results of the calculated mean shown that all the variables are somewhat affecting the decision making behavior of investor and accounting information category of variables is most influencing while advocate recommendation is the least influencing category. Frequency table of significantly influencing variables shown that out of the total 33itemsthe 6 most influencing items which belongs to the self-imagelfirm's image and accounting information like dividend paid, reputation of firm, feelings for a firm's products and services, get rich quick, firm's involvement in solving community problems, and firm's status in industry On other side factors that were found to be least influencing with respect to order of importance were friend or coworker recommendations, opinions of the firm's majority stockholder, recent price movement in the firm's stock, Religious Reason, Family member opinion and Broker recommendation related to other variable categories.
\end{abstract}

\section{Introduction}

Within behavioral finance it is assumed that characteristics of market individuals and information structure influence investment decisions of individuals and market outcomes as well. Behavioral finance says market behavior of investor for explaining the reason why people sell and buy stocks derives from the psychological principals of the decision making. The main focus of behavioral finance is upon the ways people do interpret and act upon information for making investment decisions.

As behavioral finance is defined byShefrin (1999)arapidly developing area that deals with influence of the psychology on financial practitioner behavior. Behavioral finance is the study that how psychology influences investment decision making and the financial markets. (Shefrin 2001)

A healthier understanding of the behavioral process of investors and its outcomes is significant for financial planners, because if financial planners get an understanding that how investor responds to market movements helps them in developing suitable strategies of asset allocation for their clients. Behavioral finance tries to understand and to explain that how cognitive errors and emotions affect investors decision making (Statman, 1999)

Process of decision making is a cognitive that results in selection of one course of action out of several alternatives. Many equity investors do not have appropriate knowledge of the basic concepts of economics required to make decisions of investment. So there exists a need to make research on these factors that can influence the investment decisions. (Lusardi and Mitchell, 2006)

Some empirical studies first appeared in 1970s focused on individual rather than on the aggregate investor profiles. Research in the behavioral finance formed three main theoretical streams i.e. Self-Control, Regret Aversion and Prospect Theory. These research streams caught and investigated attributes of behavior of individual investors.

Baker and Haslem (1974)identifiedthatexpected returns dividends, and financial stability of firm are the serious investment considerations for the individual investors. Baker, Haslem and Haargrove (1977) proposed, investors behave rationally and take into account investment's risk and return tradeoff.This study 
analyzed the factors that exercise the supreme influence on individual investor behavior in investment decision making in Pakistan.

\section{Objectives Of The Research}

The research aims to achieve the following objectives:

Primary Objectives

To study the different factors that influences the individual investor's investment behavior.

Secondary Objective

i. To study the influence of firm image/self-image on the individual investor behavior in making investment decisions.

ii. To identify the impact of accounting information on individual investor behavior.

iii. To identify the effect of factors those are related to the neutral information on investor behavior.

iv. To analyze the effect of advocate recommendation on investor behavior.

v. To interpret the influence of factors those are related to the personal financial needs of investor on his behavior.

vi. To identify the most influencing factor in investing decision of individual investor out of the above mentioned factors.

\section{Literature Review}

People living in the same society and having same income level are different in their investment behavior. The research indicated about factors influencing the decisions in India used two factors age and gender. They admit that various factors affect the investor's behavior. People with different age and gender have different investment behaviors. People with different ages and gender have varying persecutions. The risk level of people of different age differs as well as gender also contributes to the level risk tolerance in decision making of investments.(Mishra \& Dash, 2010)

Factors that affect the investor's behavior have their intensity to affect. The study used five factors selfimage or firm-image, accounting information, neutral information, advocate recommendation and personal financial needs. They admit that all these variables affect the investor's decision makings but with different intensity. Few have more affect and few have lesser affect. Accounting information has high intensity towards affecting investor's behavior and advocate recommendation have least effect on investors decision making.(Gnani, Ganesh \&Santhi, 2012)

The empirical factors that influence the individual investor behavior have varying degree of effects on the investors of Greeks Stock Exchange. The variables accounting information, subjective/personal, neutral information, advocate recommendation and personal financial needs were subdivided into other 27 variables. Thisstudyindicated the factors that have significant influence and the factors that have least influence on the Greek Stock Exchange investors. The research result showed the accounting information has significant and personal financial needs have least influence in Greek.(Anna, Andreas, George \& Prasad, 2004)

The conventional finance theories put emphasis on theories such as Modern Portfolio Theory as well as Efficient Market Hypothesis. The advancement of these theories in the form of behavioral finance focuses on the cognitive and emotional factors that affect the individual decision making process. This study used overconfidence, cognitive dissonance, regret theory and prospect theory. The influence of these factors was checked on the investors of Kenya (Nairobi Stock Exchange). Investors show rational as well as irrational behaviors due to different emotional and cognitive factors.(Aduda, Oduor\&Onwonga, 2012)

Saving and investment are made by different types of investors. The study described the attitude of the salaried person towards investments. Investment is very important factor in the economic development of any country. The salaried person needs security and guaranty of the investments he made out of his salary. Many new salaried people make wrong decision regarding their investments. The need appropriate guidelines for the proper investments. Government should use proper measure to assure the investments and increase the saving habits among salaried persons.(Pandiyan\&Aranganathan, 2012)

The research in Rajasthan and indicated that the investment decision is effected by the demographic factors. They have different attitudes towards decision making, some risk seekers and some risks averse. People with different ages, income level, knowledge, gender, marital status and occupation makes different decisions. (Jain \&Mandot, 2012)

The research conducted on Karachi stock exchange investors to get the factors influencing the decision making. The stock purchase decision is based upon the wealth maximization. Investors take family and friends recommendations as well as use accounting information but most of the investor's decision is based upon their own will and are not influenced by any one. Individual investor lacks skills due to which the decision making of investors suffers.(Iqbal\&Usmani, 2011) 
The research on the factors influencing the mutual fund investment indicates different factors affect the mutual fund investor's decision. Factors like past performance, facility of withdrawal of funds and the reputation of the company have significant influence on investor's decisions. These investors are also victim of different behavioral biases leading the investors towards bad decisions.(Hayat, Awan\&Arshad 2012)

The study analyzed the effect of investor feeling on decision making process. This study investigates the effect of variations in feelings of investors' decision making process. He analyzed the investor feelings in two areas. First area deals with the mood misattribution. This analyzed the effect of environmental factor such as weather, social factors on equity pricing. People in good mood take the more positive decision due to the good weather conditions. The second area deals with the impact of stocks image on investor decision making. Image of stock provoke the emotions in investors to some extent derivative of the investment behavior. Study concludes that the investor sometime invest in a company on the basis of whether he likes or dislikes a company.(Lucey, 2005)

The study investigates investor psychology and different aspects of behavior in decision making. The basic purpose of this study is to find the impact behavioral aspects and the relationship between investors' behavior and risk. He found out that investors are not always rational unlike the theories of standard finance. They are subject to several cognitive and emotional errors; they are suffering from several biases while taking the investment decision. Due to different investors' biases their perception change about risk taking. Results show that investors who are actually risk averse in their characteristics show the risk seeking behavior by holding the losing investments. (Chandra, 2008)

The research investigated factor'simpact on the investor decision. These factors include capital structure, political and media coverage, luck and financial education and trend analyses in the Nepalese capital market. Findings of the study shows that majority of the investors are youngsters and they take decision considering the media coverage and friends recommendations as good source of information. Dividend, earning, equity contribution and government control are considered the most important factors while taking the decision. Investors when bears the loss blame to the market and when earns profit take whole credit to their own abilities.(Kadariya, 2012)

In this study the four aspects that can influence the investor decision at the Amman stock exchange are examined. This study analyzed the impact of the factors include investors' age, internet usage, education and broker recommendation. They found that most of the trading is executed personally; investor should have the judgment skills. Investors' age, education and internet usage have the significant positive impact on the investor decision making. On the other hand there is a negative impact of investor and broker interaction. Investors have no trust on the brokers because they do not employ professional analyst and not giving the timely and accurate information to the investors. (Fares, 2011)

In this study researcher investigated the investors' perception of earning quality, auditor independence and the usefulness of audited financial information. He defined the earning quality as the extent to which actual and reported earning differ. He analyzed that earning quality and auditor independence have declined over time. $\mathrm{He}$ also considers whether the perception of earning quality has decreased due to more or less reliance on the audited financial statement and its usage while making a decision. He found that perceived earning quality declined with the passage of time as the perceived independence of auditor and the reliability of the financial information has decreased. In addition low perception of earning quality is related with greater reliance on financial statement has increased for decision making. (Hodge 2003)

In this study inspect the different factors influencing the decision of the investors. He analyzed the 13 factors to determine whether the investors consider these factors and decisions are influenced by these factors. He found that some of these factors are more influencing including financial statement, consulting with anybody, second hand information resources, financial ratios, reputation of the firm, profitability variable. Most important sub variable of profitability is the dividend.(Tavakoli, 2011)

In this research paper considered the factors influencing individual equity investors' decision making and their behavior. Decision making is the cognitive process and before taking a final decision we evaluate number of alternative, weight them and finally select the best alternative. While taking the decision we are influenced by different factors and change our behavior. Same is the case for the investor's decision making process. The most influencing factors found was stock marketability, past performance of the stock, recent price fluctuation, risk minimization, wealth maximization, social responsibility and expert recommendation.(Sultana, 2012)

It examined the investors' demand for disclosure of information of social responsibility in annual report. $\mathrm{He}$ analyzed the usefulness of annual report to shareholders regarding the disclosure of information. Results indicate that shareholders demand for information regarding the products' safety and quality. They demand for product safety as to save their investment. If the product quality is good and is properly protected then a company can generate revenue by maintaining a good margin for profit. He found that some shareholder also demand for the information about business practices, code of ethics, employees relation, company culture and 
corporate social responsibility by the company. And the shareholders demand for these disclosures to be audited.(Epstein, 1994)

In this study researcher investigates does the market over react? Study gave the evidence that most of the people overreact to the dramatic news. Investors' reaction to the bad news creates the mispricing of the stock traded on the NYSE. (Bondt, 1985)

He analyzed investor desires to be rational and believe that they are behaving rationally as they sought advice from the professional traders. However individual sometime select those alternative that are not maximizing their utility. This is due to the fact that human beings are emotional creatures which in themselves are barrier to rationality. And it is also because they use the heuristics while taking the decision. It is concluded that some investors behave rationally while taking decision analyze the stock considering its financial performance and dominance in the market. Some investors behave irrationally and show the herding behavior. (Aduda, 2012)

\section{Hypothesis}

Hypothesis \# 1:Self-image/firm's image has influence on the decision making behavior of investors of Pakistan. Hypothesis \# 2: Accounting information has influence on the decision making behavior of investors of Pakistan. Hypothesis \# 3:Neutral information image has influence on the decision making behavior of investors of Pakistan.

Hypothesis \# 4:Advocate recommendations have influence on the decision making behavior of investors of Pakistan.

Hypothesis \# 5:Personal financial needs have influence on the decision making behavior of investors of Pakistan.

Hypothesis \# 6:Accounting information has more influence on the decision making behavior of investors of Pakistan.

Hypothesis \# 7:Advocate recommendations have more influence on the decision making behavior of investors of Pakistan.

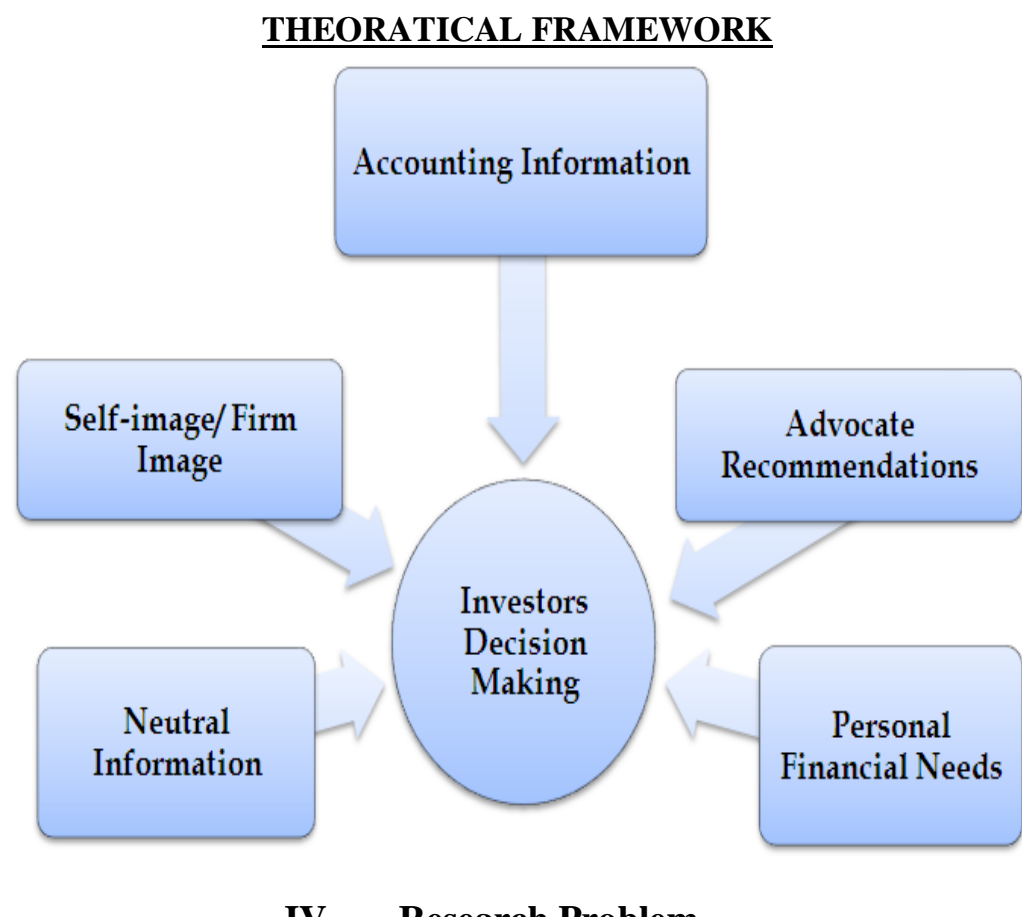

IV. Research Problem
What are the factors that influence the individual investor's decision making in Pakistan?

\section{Methodology}

Population: The population of this research is finance students, teachers and bankers of Pakistan.

Sample size: By considering the time constraints we distributed 140 questionnaires out of which 125 are received remaining unfilled and uncollected. These respondents are selectedrandomly.

Sample unit: Sample of this study includes the finance students of university of Gujarat, Finance teachers and bank employees from Gujarat, Sialkot, Lahore and Gujranwala. 


\section{Reliability Of Measure}

Table \# 1

\begin{tabular}{|l|l|c|c|}
\hline No. & Variables & $\begin{array}{l}\text { Alpha (Source Ref: H. } \\
\text { Al. Tamimi) }\end{array}$ & Alpha's Values \\
\hline $\mathbf{1}$ & Self-image/Firm's Image & $\mathbf{0 . 7 7 8}$ & $\mathbf{0 . 6 2 0}$ \\
\hline $\mathbf{2}$ & Accounting Information & $\mathbf{0 . 7 9 0}$ & $\mathbf{0 . 6 7 2}$ \\
\hline $\mathbf{3}$ & Neutral Information & $\mathbf{0 . 6 5 1}$ & $\mathbf{0 . 6 1 4}$ \\
\hline $\mathbf{4}$ & Advocate Recommendation & $\mathbf{0 . 6 1 0}$ & $\mathbf{0 . 5 8 8}$ \\
\hline $\mathbf{5}$ & Personal Financial Needs & $\mathbf{0 . 6 4 0}$ & $\mathbf{0 . 6 1 7}$ \\
\hline
\end{tabular}

\begin{tabular}{|c|c|c|}
\hline \multirow{2}{*}{\multicolumn{3}{|c|}{$\frac{\text { FACTORS AFFECTING THE INVESTOR'S DECESION }}{\text { SELF-IMAGE/FIRM IMAGE }}$}} \\
\hline & & \\
\hline 1 & \multicolumn{2}{|l|}{ Religious Reason } \\
\hline 2 & \multicolumn{2}{|l|}{ Get rich quick } \\
\hline 3 & \multicolumn{2}{|c|}{ Firm's involvement in solving community problems } \\
\hline 4 & \multicolumn{2}{|c|}{ Perceived ethics of firm } \\
\hline 5 & \multicolumn{2}{|c|}{ Feelings for a firms products and services } \\
\hline 6 & \multicolumn{2}{|c|}{ Reputation of firm's shareholder } \\
\hline 7 & \multicolumn{2}{|l|}{ Firms status in industry } \\
\hline 8 & \multicolumn{2}{|l|}{ Reputation of firm } \\
\hline \multirow[t]{3}{*}{9} & \multicolumn{2}{|c|}{ Creation of organized markets } \\
\hline & Mean & 4.9577 \\
\hline & Standard Deviation & .9038 \\
\hline \multicolumn{3}{|c|}{ ACCOUNTING INFORMATION } \\
\hline 10 & \multicolumn{2}{|c|}{ Expected corporate earning } \\
\hline 11 & \multicolumn{2}{|c|}{ Condition of financial statement } \\
\hline 12 & \multicolumn{2}{|c|}{ Past performance of firm's stock } \\
\hline 13 & \multicolumn{2}{|l|}{ Stock marketability } \\
\hline 14 & \multicolumn{2}{|l|}{ Dividend Paid } \\
\hline 15 & \multicolumn{2}{|l|}{ Affordable share price } \\
\hline \multirow[t]{3}{*}{16} & \multicolumn{2}{|l|}{ Expected Dividend } \\
\hline & Means & 4.883 \\
\hline & Standard Deviation & $\mathbf{0 . 8 5 2}$ \\
\hline \multicolumn{3}{|c|}{ NEUTRAL INFORMATION } \\
\hline 17 & \multicolumn{2}{|l|}{ Government holding } \\
\hline 18 & \multicolumn{2}{|c|}{ Statement from government officials } \\
\hline 19 & \multicolumn{2}{|c|}{ Current economic indicator } \\
\hline 20 & Information obtained & \\
\hline 21 & Coverage in the press & \\
\hline 22 & Fluctuation/developm & \\
\hline 23 & Recent price movemer & \\
\hline & Mean & 5.487 \\
\hline & Standard Deviation & 0.975 \\
\hline & $\overline{\mathrm{ADV}}$ & ANDATION \\
\hline 24 & Broker recommendatic & \\
\hline 25 & Family member opinic & \\
\hline 26 & Friend or coworker re & \\
\hline 27 & Opinions of the firm's & \\
\hline & Mean & 4.462 \\
\hline & Standard Deviation & 1.015 \\
\hline & $\overline{\text { PEI }}$ & AL NEEDS \\
\hline 28 & Attractiveness of non- & \\
\hline 29 & Diversification needs & \\
\hline 30 & Ease of obtaining borr & \\
\hline
\end{tabular}




\begin{tabular}{|l|l|l|}
\hline $\mathbf{3 1}$ & Minimizing Risk \\
\hline $\mathbf{3 2}$ & Expected losses in the local financial market \\
\hline $\mathbf{3 3}$ & Expected losses in the international market \\
\hline & Mean & $\mathbf{4 . 6 5 7}$ \\
\hline & Standard Deviation & $\mathbf{1 . 0 8 6}$ \\
\hline
\end{tabular}

Cranach alpha is measures for assessing the reliability of the questionnaire. The alpha is acceptable if it is equal or more than 0.5 and shows that the good reliability of the questions. In this study 5 categories of variables are included like self-image/firm image, accounting information, neutral information, advocate recommendation, and personal financial needs. The Cranach alpha is respectively $0.620,0.672,0.414,0.588$, and 0.617 , show that all variables reliable.

\section{RESULT}

Table \# 2Mean and Standard Deviation

In the above table the mean and standard deviation of the five categories of the variables self-image, accounting information, neutral information, advocate recommendation, and personal financial needs is calculated. The above calculation shows that the value of all variable mean and is positive which means that all 34 factors that were included in questionnaire are someway affecting the Pakistani investor's decision making in investment. The calculation of mean and standard deviations indicate the effect of all items on decision making of individual investor but these do not describe the degree of influence on the decision making of an individual. So for this purpose Table \# 3 and Table \# 4 are shown below.

\section{Table \# 3}

\begin{tabular}{|c|c|c|c|}
\hline \multicolumn{4}{|c|}{ FACTORS INFLUENCING SIGNIFICANTLY TO THE INVESTOR'S DECESION MAKING } \\
\hline NO. & ITEMS & FREQUENCY & PERCENTAGE \\
\hline $\mathbf{1}$ & Dividend Paid & 97 & $77.6 \%$ \\
\hline 2 & Reputation of firm & 89 & $71.2 \%$ \\
\hline 3 & Feelings for a firms products and services & 89 & $71.2 \%$ \\
\hline 4 & Get rich quick & 88 & $70.4 \%$ \\
\hline 5 & Firm's involvement in solving community problems & 86 & $68.8 \%$ \\
\hline 6 & Firms status in industry & 79 & $63.2 \%$ \\
\hline 7 & Expected Dividend & 78 & $62.4 \%$ \\
\hline 8 & Perceived ethics of firm & 76 & $60.8 \%$ \\
\hline 9 & Affordable share price & 75 & $60 \%$ \\
\hline 10 & Reputation of firm's shareholder & 73 & $58.4 \%$ \\
\hline 11 & Religious Reason & 63 & $50.6 \%$ \\
\hline 12 & Friend or coworker recommendations & 63 & $50.4 \%$ \\
\hline 13 & Government holding & 62 & $49.6 \%$ \\
\hline 14 & Expected losses in the local financial market & 62 & $48.6 \%$ \\
\hline 15 & Ease of obtaining borrowed funds & 59 & $47.2 \%$ \\
\hline 16 & Fluctuation/development in the stock index & 57 & $45.6 \%$ \\
\hline 17 & Statement from government officials & 57 & $45.6 \%$ \\
\hline 18 & Coverage in the press & 56 & $44.8 \%$ \\
\hline 19 & Diversification needs & 56 & $44.8 \%$ \\
\hline 20 & Minimizing Risk & 56 & $44.8 \%$ \\
\hline 21 & Current economic indicator & 55 & $44 \%$ \\
\hline 22 & Expected corporate earning & 50 & $40 \%$ \\
\hline 23 & Family member opinion & 48 & $39 \%$ \\
\hline 24 & Expected losses in the international market & 48 & $38.4 \%$ \\
\hline 25 & Creation of financial organized markets & 47 & $37.6 \%$ \\
\hline 26 & Past performance of firm's stock & 47 & $37.6 \%$ \\
\hline 27 & Recent price movement in the firm's stock & 47 & $37.6 \%$ \\
\hline 28 & Broker recommendation & 40 & $32 \%$ \\
\hline 29 & Information obtained from internet & 36 & $28.8 \%$ \\
\hline 30 & Condition of financial statement & 35 & $28 \%$ \\
\hline 31 & Stock marketability & 32 & $25.6 \%$ \\
\hline
\end{tabular}




\begin{tabular}{|l|l|c|c|}
\hline $\mathbf{3 2}$ & Opinions of the firm's majority stockholder & 29 & $23.2 \%$ \\
\hline $\mathbf{3 3}$ & Attractiveness of non-stock investment & 20 & $16 \%$ \\
\hline
\end{tabular}

This research has shown that dividend paid reputation of the firm, feeling for firm's products, get rich quick and firm's involvement in solving community problems are high on list of criteria that is considered by a high percentage of individual investors i.e. $77.6 \%, 71.2 \%, 71.2 \%, 70.4 \%$ and $68.8 \%$ while choosing stock investments. On the other hand conditions of financial markets, stock marketability, opinion of firm's majority stock holders and attractiveness of non-stock investment are the least important factors to most investors while making investment decision i.e. $28 \%, 25.6 \%, 23.2 \%$ and $16 \%$ and very percentage of individual investors considers them important investment decision criteria.

Table \# 4

\begin{tabular}{|l|l|c|c|}
\hline \multicolumn{5}{|c}{ LEAST INFLUENCING FACTORS TO THE DECISION MAKING } \\
\hline NO. & ITEMS & FREQUENCY & PERCENTAGE \\
\hline $\mathbf{1}$ & Friend or coworker recommendations & 43 & $34.4 \%$ \\
\hline $\mathbf{2}$ & Opinions of the firm's majority stockholder & 41 & $32.8 \%$ \\
\hline $\mathbf{3}$ & Recent price movement in the firm's stock & 35 & $28 \%$ \\
\hline $\mathbf{4}$ & Religious Reason & 30 & $29 \%$ \\
\hline $\mathbf{5}$ & Family member opinion & 29 & $23.2 \%$ \\
\hline $\mathbf{6}$ & Broker recommendation & 29 & $23.2 \%$ \\
\hline $\mathbf{7}$ & Attractiveness of non-stock investment & 25 & $20 \%$ \\
\hline $\mathbf{8}$ & Expected losses in the local financial market & 25 & $20 \%$ \\
\hline $\mathbf{9}$ & Creation of financial organized markets & 23 & $18.4 \%$ \\
\hline $\mathbf{1 0}$ & Expected losses in the international market & 22 & $17.50 \%$ \\
\hline $\mathbf{1 1}$ & Reputation of firm's shareholder & 22 & $17.5 \%$ \\
\hline $\mathbf{1 2}$ & Diversification needs & 21 & $16.8 \%$ \\
\hline $\mathbf{1 3}$ & Government holding & 21 & $16.8 \%$ \\
\hline $\mathbf{1 4}$ & Fluctuation/development in the stock index & 20 & $16 \%$ \\
\hline $\mathbf{1 5}$ & Statement from government officials & 20 & $16 \%$ \\
\hline $\mathbf{1 6}$ & Perceived ethics of firm & 19 & $15.2 \%$ \\
\hline $\mathbf{1 7}$ & Ease of obtaining borrowed funds & 19 & $15.2 \%$ \\
\hline $\mathbf{1 8}$ & Firms status in industry & 18 & $14 \%$ \\
\hline $\mathbf{1 9}$ & Dividend Paid & 18 & $14 \%$ \\
\hline $\mathbf{2 0}$ & Information obtained from internet & 16 & $12.8 \%$ \\
\hline $\mathbf{2 1}$ & Past performance of firm's stock & 16 & $12.8 \%$ \\
\hline $\mathbf{2 2}$ & Coverage in the press & 16 & $12.8 \%$ \\
\hline $\mathbf{2 3}$ & Stock marketability & 15 & $12 \%$ \\
\hline $\mathbf{2 4}$ & Expected corporate earning & 15 & $12 \%$ \\
\hline $\mathbf{2 5}$ & Firm's involvement in solving community problems & 14 & $11 \%$ \\
\hline $\mathbf{2 6}$ & Feelings for a firms products and services & 13 & $10.4 \%$ \\
\hline $\mathbf{2 7}$ & Current economic indicator & 13 & $10.4 \%$ \\
\hline $\mathbf{2 8}$ & Minimizing Risk & 12 & $9.6 \%$ \\
\hline $\mathbf{2 9}$ & Condition of financial statement & 11 & $8.8 \%$ \\
\hline $\mathbf{3 0}$ & Affordable share price & 9 & $7 \%$ \\
\hline $\mathbf{3 1}$ & Get rich quick & 9 & $7 \%$ \\
\hline $\mathbf{3 2}$ & Expected Dividend & 6 & $4.8 \%$ \\
\hline $\mathbf{3 3}$ & Reputation of firm & & 3.2 \\
\hline & & 4 & \\
\hline
\end{tabular}

The results of the above table has shown that the six variables that have least influencing on individual investor while making investment decisions are by the order of importance are Friend or coworker recommendations, Opinions of the firm's majority stockholder, recent price movement in the firm's stock, Religious Reason, Family member opinion and Broker recommendation having respective percentages 34.4\%, 32.8, 28\%, 29\%, $23.2 \%$ and $23.2 \%$.

\section{SIGNIFICANCE OF STUDY}

This study has significance for the individual investors, financial advisors, companies listed in Pakistan's stock exchanges and Government. For the investors, the factors that influence their decision making are crucial as this will influence their financial plans of future. For companies identification of the most influencing factors that 
influence the behavior of their investor will affect their future strategies and plans. For financial advisors identification of these factors will help them to suggest investments that best fits them. And finally for the government, identification of the most influencing factors will help it to modify required legislation and other procedures that are needed for satisfying the desires of investors and also giving more support to the market efficiency.

\section{Conclusion}

This study was aimed at identifying the variables that have most and the least influence factors on the investor's investment behavior. There were 33 items belongs to five main categories taken as independent: selfimage/firm image, neutral information, accounting information, personal financial needs and advocate recommendation. The results according to calculated mean shown that all variables are somewhat affecting the decision making behavior of individual investors of Pakistan. Most important category by order of importance was: accounting information, self-image/firm image, personal financial needs, neutral information and advocate recommendation. And out of all variables the most influencing 6 items by the order of importance were dividend paid, reputation of firm, feelings for a firm's products and services, get rich quick, firm's involvement in solving community problems, and firm's status in industry related to firm's image/self-image and accounting information. And the 6 least influencing factors with the other classes of selected variables were Friend or coworker recommendations, Opinions of the firm's majority stockholder, recent price movement in the firm's stock, Religious Reason, Family member opinion and Broker recommendation. This study supports the entire hypothesis. The reason of least influencing factors is the people of the Pakistan mostly have no knowledge about these factors like creation of organized market. There is no organized market in the Pakistan so the investors don't know about the effect of it on the investment decision.

\section{References:}

[1]. PandiyanandAranganathan, (May-June 2012) "Savings and Investments Attitude of Salaried Class in CUDDALORE District", IOSR Journal of Business and Management (IOSRJBM) Volume 1, Issue 1, PP 40-49

[2]. Jain, D and Mandot, N. (2012) "'Impact of Demographic Factors on Investment. Decision of Investors in Rajasthan", Issue-2 (3),

[3]. Awan, H andArshad, S (2012) "Factors valued by investors while investing in mutual funds-a behavioral context", Interdisciplinary journal of contemporary research in business, Volume 4 , no 1

[4]. Iqbal,A and Usmani, S(2009)"'Factors Influencing Individual Investor Behavior"' South Asian Journal of Management Sciences, Vol. 3, No. 1, Page no, $15-26$

[5]. Kabra, Mishra and Dash. (2010). "Factors Influencing Investment Decision of Generations in India": An Econometric Study, Asian Journal of Management Research.

[6]. Anna A.M, Andreas, G.M, George, S.V. (2004) ''Economic Factors.And Individual Investor Behavior''The Case of the Greek Stock Exchange, Volume 20, 93. Prasad Journal of Applied Business Research.

[7]. Lusardi, A \& Mitchell, OS (2006), “Financial Literacy and Planning: Implications for Retirement Wellbeing”, Pension Research Working Paper, Pension Research Council, Wharton School University of the University of Pennsylvania, Philadelphia.

[8]. Lucey\& Dowling, M (2005) “The Role of Feelings in Investor Decision-making” Journal of economic surveys vol. 19, no. 2\# Blackwell publishing ltd. 2005, 9600

[9]. Kadariya.S, (2012) 'Factors affecting investor decision making: A case of Nepalese capital market' 'Journal of Research in Economics and International Finance (JREIF), Vol. 1(1) Page. 16-30,

[10]. Sultan.T.S\&Pardhasaradhi.S,(2012)S " An Empirical Analysis of Factors Influencing Individual equity Investors Decision Making and Behavior' 'European Journal of Business and Management, Volume 4, No.18,2012,Page 50-62

[11]. Aduda.J, Oduor.E.O\&Onwonga.M (2012), " The Behavior and Financial Performance of Individual Investors in the Trading Shares of Companies Listed At the Nairobi Stock Exchange, Kenya' 'Journal of Finance and Investment Analysis, Volume.1, no.3, 2012, Page no 33-60

[12]. Werner F.M \&Thaler R, (1985), "' Does the Stock Market Overreact", The Journal of Finance, Volume 40, No.3, Page no. 783-805

[13]. Hodge.D.F, (2003), Investors perception of earning Quality, Auditor Independence, and usefulness of the Auditor Financial Information", Accounting Horizon page no.37-48

[14]. Tavakoli.R.M, Tanha.H.F, \&Halid.N. (2011) " A study on small investors' behavior in choosing stock case study: Kuala-Lumpur stock market', African Journal of Business Management, Vol. 5(27), pp. 11082-11092, 9 November, 2011

[15]. Chandra. A, (2008) 'Decision Making in the Stock Market: Incorporating Psychology with Finance' 'National Conference: FFMI 2008 IIT Kharagpur

[16]. Lucey.M.B,' (2011), The Role of Feeling in Investor Decision making' 'School of Business Studies and Institute for International Integration Studies, Trinity College

[17]. Lusardi, A \& Mitchell, OS (2006), 'Financial Literacy and Planning: Implications for Retirement Wellbeing', Pension Research Working Paper, Pension Research Council, Wharton School University of the University of Pennsylvania, Philadelphia

[18]. Kahneman.D\&Tversky.A, (1979), 'Prospect Theory: An Analysis of Decision under Risk', Econometrica (pre-1986); Volume no. 47,2

[19]. Baker, H.K. \& J.A. Haslem, (1974) “Toward the Development of Client-Specified Valuation Models," Journal of Finance, Volume. 29, No. 4, pp. 1255-1263

[20]. Baker, H.K., M.B. Hargrove, and J.A. Haslem, (1977) "An Empirical Analysis of the Risk Return Preferences of Individual Investors," Journal of Financial and Quantitative Analysis, Vol. 12, No. 3, pp. 377-389, 